\title{
How Does Abrupt Economic Shock Impact Exchange Rate Movement: Empirical Evidences from Bangladesh
}

\author{
Kazi Rashedul Hasan ${ }^{1}$, Ariful Malek ${ }^{2}$ \\ ${ }^{1}$ Department of Finance, American International University-Bangladesh (AIUB), Dhaka, Bangladesh \\ ${ }^{2}$ Trade Finance, National Bank Limited, Dhaka, Bangladesh
}

Email address:

kazihasan@aiub.edu (K. R. Hasan), arif.martt@gmail.com (A. Malek)

\section{To cite this article:}

Kazi Rashedul Hasan, Ariful Malek. How Does Abrupt Economic Shock Impact Exchange Rate Movement: Empirical Evidences from Bangladesh. Journal of Finance and Accounting. Vol. 4, No. 6, 2016, pp. 310-320. doi: 10.11648/j.jfa.20160406.11

Received: September 17, 2016; Accepted: September 28, 2016; Published: October 19, 2016

\begin{abstract}
The primary focus of this research is to study the impact of Foreign Exchange Reserve changes on key economic indicators, namely Inflation and the Exchange Rate of Bangladesh. In addition, the article seeks to illustrate the effects of recent theft from Bangladesh Bank's reserve on Bangladeshi economy and exchange rate movement, based on multiple hypotheses: whether or not the changes in foreign exchange reserve can solely dictate the trend of the exchange rate; whether or not the changes in foreign exchange reserve can solely dictate the trend on inflation rate; whether or not the foreign exchange reserve kept increasing because of exports and increased inward remittance; and finally, how effective was Bangladesh Bank's policy intervention tools to keep the economy in balance.
\end{abstract}

Keywords: Foreign Exchange Reserve, Economic Shock, Inflation, Policy Intervention Tools, Exchange Rate Movement, Pearson Correlation

\section{Introduction}

The following purposes will be served upon completion of the study -

a) To find the impact on Bangladeshi economy from swings in foreign exchange reserves.

b) To find the correlation of foreign exchange reserve with inflation and exchange rate movement;

c) To find the economic impacts due to swings in foreign exchange reserves;

d) To evaluate the effectiveness of Bangladesh Bank's exchange rate controlling policy \& mechanism.

Though the coverage of this study will be limited to only the Foreign Exchange officials of National Bank Limited, and Offshore Banking Unit about the economic effects of reserve in recent times, interviewing officials of Bangladesh Bank's Foreign Exchange Policy department about the recent reserve theft and the policies that may have somewhat neutralized the abrupt economic shock.

The primary data were collected by the following methods:

(1) Questionnaires,

(2) Interviews;
The secondary data were collected by the following methods:

(1) Bangladesh Bank's publications,

(2) News sites;

The statistical tests performed with the collected data include the following:

(1) Correlations,

(2) Mean,

(3) Median;

Analysis Tools:

The following statistical application was used for analysis: IBM SPSS

\section{Literature Review}

From Bangladesh Bank's Special Report No. 1502 entitled "Link between the Financial Inclusion and Economic Growth: Unconventional Monetary Policy in Bangladesh", it is established that the during the time period of publication of the report, Bangladeshi economy has experienced an average 6 percent growth in the GDP, which was much below policymakers' expectations. This led the regulators undertake 
flexible monetary policies regarding trade business. The article predicts a periodical strategic adjustment with the changing economic aspects of Bangladesh economy. (Younus, Link between the Financial Inclusion and Economic Growth: Unconventional Monetary Policy in Bangladesh, 2010). It is discussed in references [1] and [2].

Bangladesh Bank's Working Paper Series: WP 1302 entitled "Effects of Monetary Policy on Capital Market in Bangladesh" estimates the degree of changes in the capital market and subsequently the exchange rate and domestic inflation rate to come along with the monetary policies in effect. This research paper supports our findings that regulators intervened with other tools to stabilize inflation and influence exchange rate movements. (Khan, Hossain, \& Rahman, 2013). They are referenced in [3] and [4].

From Bangladesh Bank's Working Paper Series: WP 1305 entitled "Sources of Exchange Rate Fluctuations in Bangladesh" it was found that exchange rate fluctuations are favorable to the economic growth, but it may also be an obstacle for macroeconomic growth, if there were excessive fluctuations in the exchange rate. Thus, policymakers focused on keeping the exchange rate stable with their tools at hand such as export and import policies, policies regarding inward and outward remittance, as well as the policies to do with foreign direct investments, and liquidity movement of the foreign currency. This supports our findings that Bangladesh Bank intervened with the exchange rate movements with their tools at hand to keep the exchange rate stable. (Akther, Sarker, \& Khan, 2013). [5]

From Bangladesh Bank's Working Paper Series: WP 1401 entitled "Some Facts and Determinants of CPI Inflation in Bangladesh: Evidence from Post-Floating Exchange Rate Regime" it was found that inflation affects the import and export costs and thereby affects the net export and thereby affects the exchange rate by affecting the foreign exchange reserves, because the materials and services related to export and imports are inclusive to the basket which is used for the Consumer Pricing Index. This study also reaffirms our finding that the foreign exchange reserve affects the inflation rate and vice versa. (Younus, Some Facts and Determinants of CPI Inflation in Bangladesh: Evidence from Post-Floating Exchange Rate Regime, 2014). [6]

From the empirical study in Bangladesh Bank's Working Paper Series: WP 1402 entitled "The Demand for International Reserves of Bangladesh" it is seen that exchange rate flexibility plays an essential role in Bangladesh's reserves demand, which is vital for a nation's economic growth, but the central bank has incentives to gather reserves to avoid excessive fluctuations and keep exchange rate volatility within a narrow band. The theory found in this study also echoes our findings. (Afrin, Sarder, \& Nabi, 2014). [7]

From Bangladesh Bank's Working Paper Series: WP 1404 entitled "Reserve Accumulation and Sterilized Intervention in the Foreign Exchange Market in Bangladesh: An Empirical Analysis" it can be found that Bangladesh Bank has frequently intervened in the foreign exchange market to keep the exchange shield at their desired level, by complementing the ratio between NFA (Net Foreign Assets) and NDA (Net Domestic Assets) to find an equilibrium as per their desire. This also supports our premise that the policies were modified to keep the exchange rate stable. (Begum, 2014). [8]

From Bangladesh Bank's Working Paper Series: WP 1408 entitled "Real Exchange Rate and Its Impact on Export, Import, and Trade Balance: Is there any $\mathrm{J}$ curve effect in Bangladesh?" it can be observed that the hypothesis assumed was rejected, and there is no $\mathrm{J}$ curve effect in the balance of trade, and therefore, no devaluation or depreciation of the local currency. This supports our findings that the exchange rate changes were insignificant. (Younus \& Chowdhury, Real Exchange Rate and Its Impact on Export, Import and Trade Balance: Is there any J curve effect in Bangladesh? 2014). [9]

Findings from Bangladesh Bank's Working Paper Series: WP 1605 entitled "The Impact of Real Effective Exchange Rate on Real Export Earnings in Bangladesh" suggest that to control inflation and maintain exchange rate stability, the central bank tries to sterilize the excess capital inflows through open market operations. This theory proves that Bangladesh Bank is able to govern the economy with their monetary policies, which helps them control the stability of the exchange rate at their desired level, which is fundamental to one of our four hypotheses. (Hassan, Chakraborty, Sultana, \& Rahman, 2016). [10]

From Bangladesh Bank's Working Paper Series: WP 1606 entitled "Real or Nominal Shock: What Drives the Exchange Rate Movements in Bangladesh" it can be seen a real shock such as the heist of the Bangladesh Bank Reserve takes a few months to have a negative effect on the exchange rate. (Sarker, Hasan, \& Rahaman, 2016). [11] and [12]

\section{Foreign Exchange Reserve Data Summary}

The following table is formed with the exchange rate and inflation data found on Bangladesh Bank's website from July 2014 to June 2016:

Table 1. Foreign Exchange Reserve, Exchange Rate \& Inflation.

\begin{tabular}{lllll}
\hline Month Period & $\begin{array}{l}\text { Foreign Exchange Reserve (US } \\
\text { Dollars, in Million) }\end{array}$ & $\begin{array}{l}\text { Exchange Rate (BDT/USD, } \\
\text { End of Month) }\end{array}$ & $\begin{array}{l}\text { Inflation (Monthly Average, } \\
\text { Twelve Month) }\end{array}$ & $\begin{array}{l}\text { Inflation (Point to } \\
\text { Point) }\end{array}$ \\
\hline July, 2014 & $\$ 21,383.50$ & 77.5000 & $7.28 \%$ & $6.97 \%$ \\
August, 2014 & $\$ 22,070.40$ & 77.4000 & $7.24 \%$ & $6.91 \%$ \\
September, 2014 & $\$ 21,836.60$ & 77.4000 & $7.22 \%$ & $6.84 \%$ \\
October, 2014 & $\$ 22,312.40$ & 77.4000 & $7.18 \%$ & $6.60 \%$ \\
November, 2014 & $\$ 21,590.00$ & 77.7000 & $7.10 \%$ & $6.21 \%$ \\
\hline
\end{tabular}




\begin{tabular}{|c|c|c|c|c|}
\hline Month Period & $\begin{array}{l}\text { Foreign Exchange Reserve (US } \\
\text { Dollars, in Million) }\end{array}$ & $\begin{array}{l}\text { Exchange Rate (BDT/USD, } \\
\text { End of Month) }\end{array}$ & $\begin{array}{l}\text { Inflation (Monthly Average, } \\
\text { Twelve Month) }\end{array}$ & $\begin{array}{l}\text { Inflation (Point to } \\
\text { Point) }\end{array}$ \\
\hline December, 2014 & $\$ 22,309.80$ & 77.9500 & $6.99 \%$ & $6.11 \%$ \\
\hline January, 2015 & $\$ 22,042.30$ & 77.8000 & $6.87 \%$ & $6.04 \%$ \\
\hline February, 2015 & $\$ 23,031.50$ & 77.8000 & $6.76 \%$ & $6.14 \%$ \\
\hline March, 2015 & $\$ 23,052.90$ & 77.8000 & $6.66 \%$ & $6.27 \%$ \\
\hline April, 2015 & $\$ 24,071.70$ & 77.8000 & $6.57 \%$ & $6.32 \%$ \\
\hline June, 2015 & $\$ 25,025.20$ & 77.8000 & $6.25 \%$ & $6.36 \%$ \\
\hline July, 2015 & $\$ 25,469.10$ & 77.8000 & $6.40 \%$ & $6.35 \%$ \\
\hline August, 2015 & $\$ 26,175.30$ & 77.8000 & $6.29 \%$ & $6.17 \%$ \\
\hline September, 2015 & $\$ 26,379.00$ & 77.8000 & $6.24 \%$ & $6.24 \%$ \\
\hline October, 2015 & $\$ 27,058.40$ & 78.0000 & $6.21 \%$ & $6.19 \%$ \\
\hline November, 2015 & $\$ 26,407.60$ & 78.9400 & $6.20 \%$ & $6.05 \%$ \\
\hline December, 2015 & $\$ 27,058.40$ & 78.5000 & $6.19 \%$ & $6.10 \%$ \\
\hline February, 2016 & $\$ 28,058.50$ & 78.4500 & $6.15 \%$ & $5.62 \%$ \\
\hline March, 2016 & $\$ 28,265.90$ & 78.4000 & $6.10 \%$ & $5.65 \%$ \\
\hline April, 2016 & $\$ 29,106.20$ & 78.4000 & $6.04 \%$ & $5.61 \%$ \\
\hline May, 2016 & $\$ 28,802.90$ & 78.4000 & $5.98 \%$ & $5.45 \%$ \\
\hline June, 2016 & $\$ 30,137.60$ & 78.4000 & $5.92 \%$ & $5.53 \%$ \\
\hline
\end{tabular}

Table 2. Pearson Correlations.

\begin{tabular}{|c|c|c|c|c|}
\hline Correlations (Calculated with IBM SPS & & $\begin{array}{l}\text { Foreign Exchange Reserve (US } \\
\text { Dollar, in Million) }\end{array}$ & $\begin{array}{l}\text { Exchange Rate } \\
\text { (BDT/USD) }\end{array}$ & $\begin{array}{l}\text { Inflation } \\
\text { (Point to Point) }\end{array}$ \\
\hline \multirow{3}{*}{$\begin{array}{l}\text { Foreign Exchange Reserve (US Dollar, } \\
\text { in Million) }\end{array}$} & Pearson Correlation & 1 & $.796^{* *}$ & $-.787^{* *}$ \\
\hline & Sig. (2-tailed) & & .000 & .000 \\
\hline & $\mathrm{N}$ & 24 & 24 & 24 \\
\hline \multirow{3}{*}{ Exchange Rate (BDT/USD) } & Pearson Correlation & $.796^{* *}$ & 1 & $-.782^{* *}$ \\
\hline & Sig. (2-tailed) & .000 & & .000 \\
\hline & $\mathrm{N}$ & 24 & 24 & 24 \\
\hline \multirow{3}{*}{ Inflation (Point to Point) } & Pearson Correlation & $-.787^{* *}$ & $-.782^{* *}$ & 1 \\
\hline & Sig. (2-tailed) & .000 & .000 & \\
\hline & $\mathrm{N}$ & 24 & 24 & 24 \\
\hline
\end{tabular}

**. Correlation is significant at the 0.01 level (2-tailed).

\section{Analytical Interpretations:}

With the Pearson Correlation Model, we have analyzed the data with SPSS, and the above results came in, wherein it's observable that the Exchange Rate has a strong positive relationship with the Foreign Exchange Reserve, and the rate of inflation has an adverse relationship with the Foreign Exchange Reserve. Hence, according to the data analyzed, if the Foreign Exchange Reserve go up in volume, the rate of interest will go down and Exchange Rate of USD against BDT will go up. The latter opposes the common principle of economy, as an increased supply of Foreign Currency always calls for depreciation in that specific foreign currency, so Bangladesh Bank must have played with the monetary policies and other economic tools to keep the exchange rate steady.

\section{Survey Data Interpretation and Analysis}

As stated earlier, surveys were done to match with the recorded data in Bangladesh Bank archives. The data found in the survey were placed in SPSS to find the accurate frequency and percentage of the responses from the respondents, and graphed accordingly with a proceeding interpretation and analysis.

\subsection{Exchange Rate of US Dollar Changes Very Frequently with Respect to the Local Currency}

Table 3. Frequency and Percentage Calculations of Survey Data.

\begin{tabular}{llllll}
\hline & Frequency & Percent & Valid Percent & Cumulative Percent & 54.8 \\
\hline \multirow{6}{*}{ Valid } & Strongly Disagree & 17 & 54.8 & 54.8 & 90.3 \\
& Disagree & 11 & 35.5 & 35.5 & 96.8 \\
& Neutral & 2 & 6.5 & 6.5 & 100.0 \\
& Agree & 1 & 3.2 & 3.2 & 100.0 \\
\hline
\end{tabular}




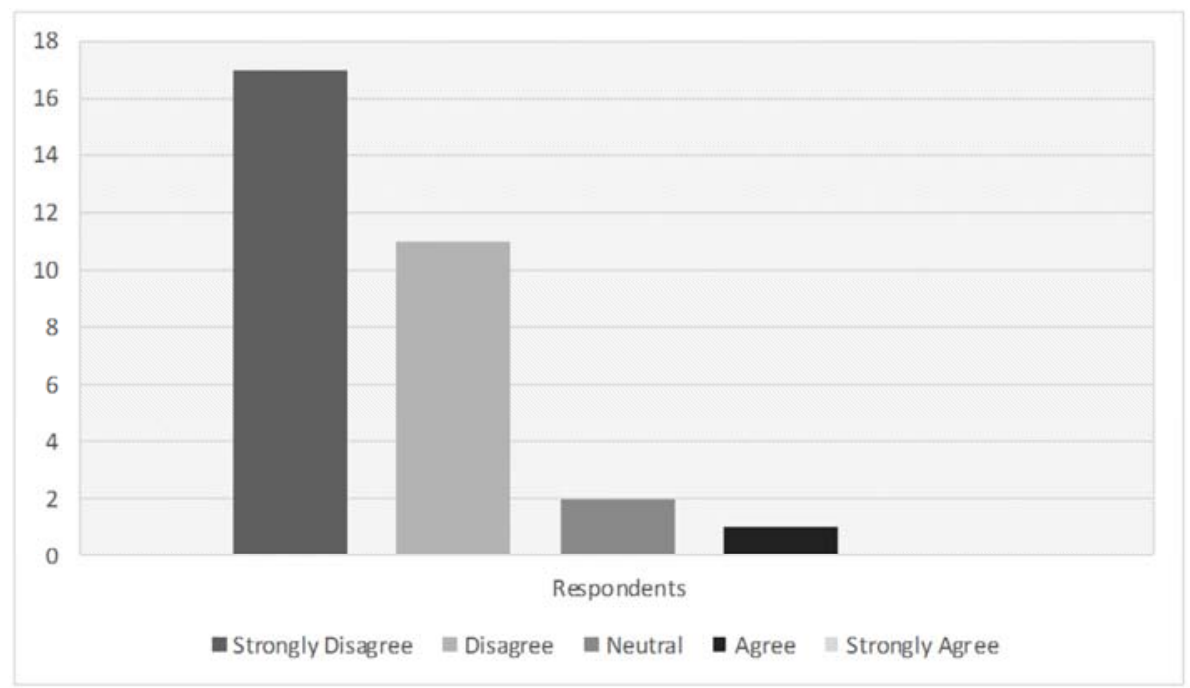

Figure 1. Frequency and Percentage Calculations of Survey Data.

Analytical Interpretations:

As per the survey data show, 54.80 percentile of the surveyed officials responded with a strongly negative, and a cumulative 90.30 percentile of them responded with response in the negative side when asked if the Exchange Rate of US Dollar changes very frequently with respect to the local currency. We have also asked them why that is, the common response that we received was that for the past 6 months, the exchange rate is not moving at all for the said Authorized Dealer (National Bank Limited). This might be a reason for concern as in a country of managed floating currency, it is not possible to have the exchange rate stable while the economy is always on the move.

\subsection{Banks Make a Good Portion of Their Foreign Exchange Income Through the Value of USD Appreciating Against BDT}

Table 4. Frequency and Percentage Calculations of Survey Opinions.

\begin{tabular}{llllll}
\hline & & Frequency & Percent & Valid Percent & Cumulative Percent \\
\hline \multirow{4}{*}{ Valid } & Disagree & 4 & 12.9 & 12.9 & 12.9 \\
& Neutral & 3 & 9.7 & 9.7 & 22.6 \\
& Agree & 12 & 38.7 & 38.7 & 61.3 \\
& Strongly Agree & 12 & 38.7 & 38.7 & 100.0 \\
\hline
\end{tabular}

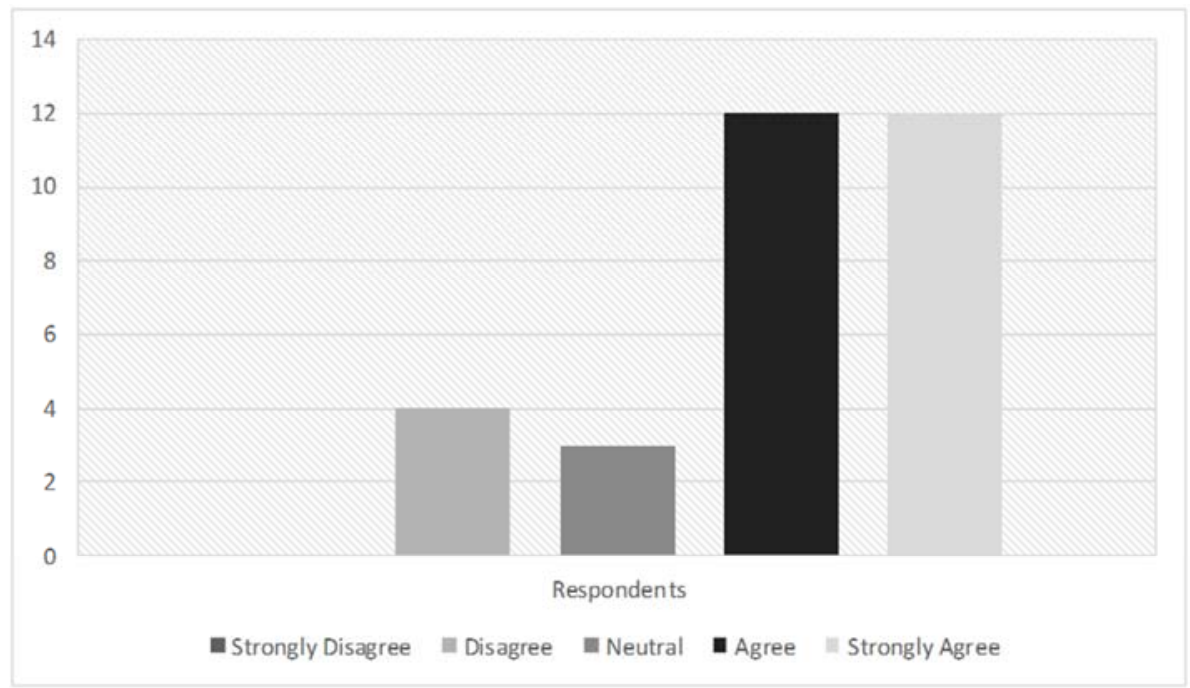

Figure 2. Frequency and Percentage Calculations of Survey Opinions.

Analytical Interpretations:

As per the data and graphical charts show, 12.90 percentile of the respondents do not earn much for their company (in their respective desks) with the appreciating value of USD against BDT, and 9.70 percentile of them do not find it relevant to their 
desks, whereas the rest 77.40 percent earn a good amount of profit through exchange earnings that incurs with the appreciating value of USD. We have asked them whether or not they can place it on the top 3 amongst the biggest earning source for Authorized Dealer banks, to which they have answered positively.

\subsection{The Exchange Rate Fluctuations Are Favorable to the Bangladeshi Economy}

Table 5. Frequency and Percentage Calculations of Survey Opinions.

\begin{tabular}{llllll}
\hline & Frequency & Percent & Valid Percent & Cumulative Percent \\
\hline \multirow{4}{*}{ Valid } & Strongly Disagree & 3 & 9.7 & 9.7 & 9.7 \\
& Disagree & 5 & 16.1 & 16.1 & 25.8 \\
& Neutral & 10 & 32.3 & 32.3 & 58.1 \\
& Agree & 11 & 35.5 & 35.5 & 93.5 \\
& Strongly Agree & 2 & 6.5 & 6.5 & 100.0 \\
\hline
\end{tabular}

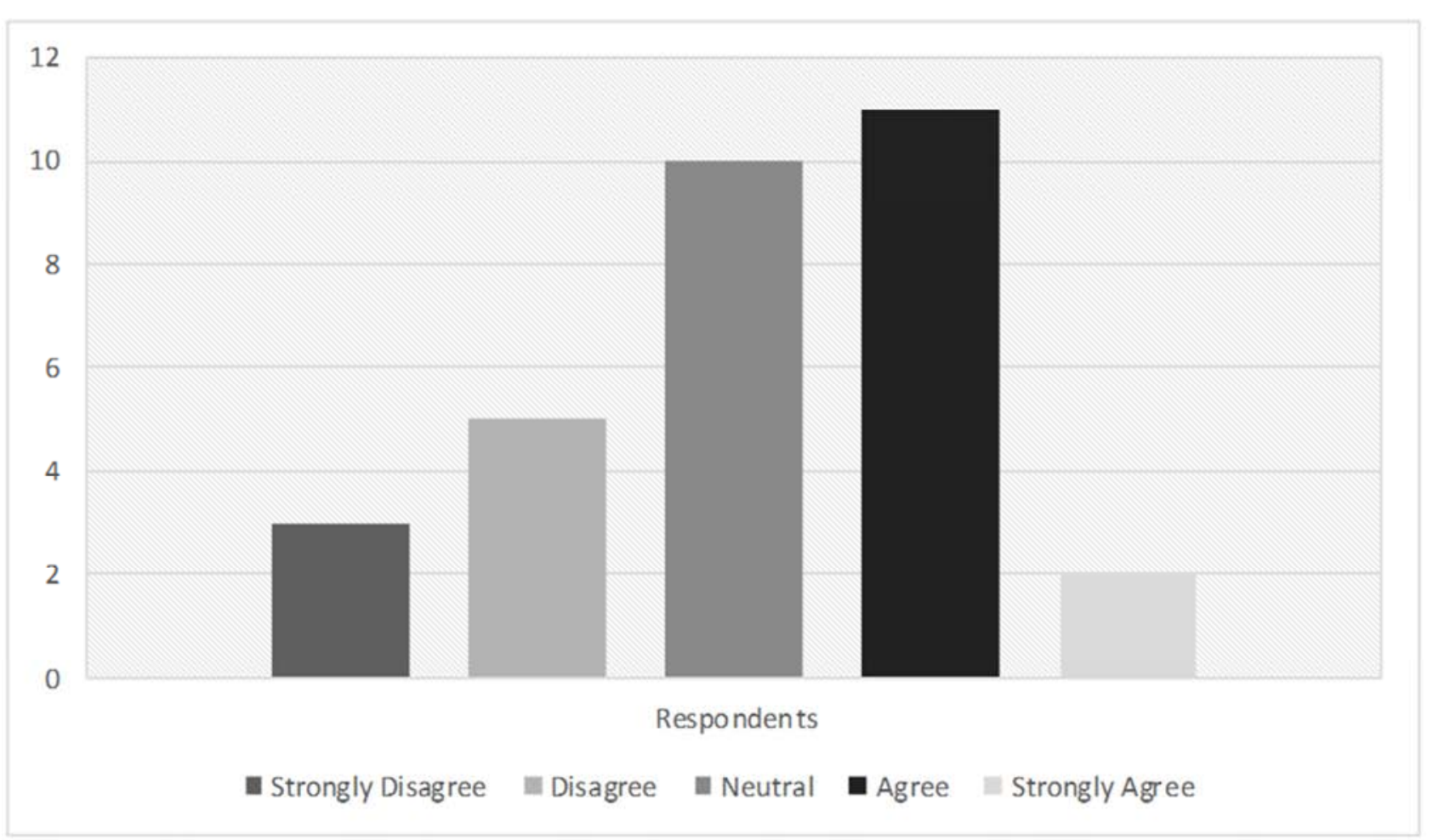

Figure 3. Frequency and Percentage Calculations of Survey Opinions.

Analytical Interpretations:

The answers from respondents varied a lot, but majority of them answered in the positive side. We have asked the respondents why would there be such big of a variance in the responses, and they replied that it depends on the direction of movement. Since the exchange rate has increased in the past two years for USD, more than one third of the surveyed pupil agreed that it is favorable to Bangladeshi economy. However, this may be added referring to the results of the immediate previous survey question, that exchange earnings are one of the major sources of Authorized Dealer banks, and the banking sector contributing most towards the Bangladeshi economy, helping the GDP, the exchange rate fluctuation does indeed help the national economy.

\subsection{Purchasing Power of People Has Increased in Bangladesh over the Year}

Table 6. Frequency and Percentage Calculations of Survey Opinions.

\begin{tabular}{llllll}
\hline & & Frequency & Percent & Valid Percent & Cumulative Percent \\
\hline \multirow{4}{*}{ Valid } & Strongly Disagree & 1 & 3.2 & 3.2 & 3.2 \\
& Disagree & 6 & 19.4 & 19.4 & 22.6 \\
& Neutral & 8 & 25.8 & 25.8 & 48.4 \\
& Agree & 12 & 38.7 & 38.7 & 87.1 \\
& Strongly Agree & 4 & 12.9 & 12.9 & 100.0 \\
& Total & 31 & 100.0 & 100.0 & \\
\hline
\end{tabular}




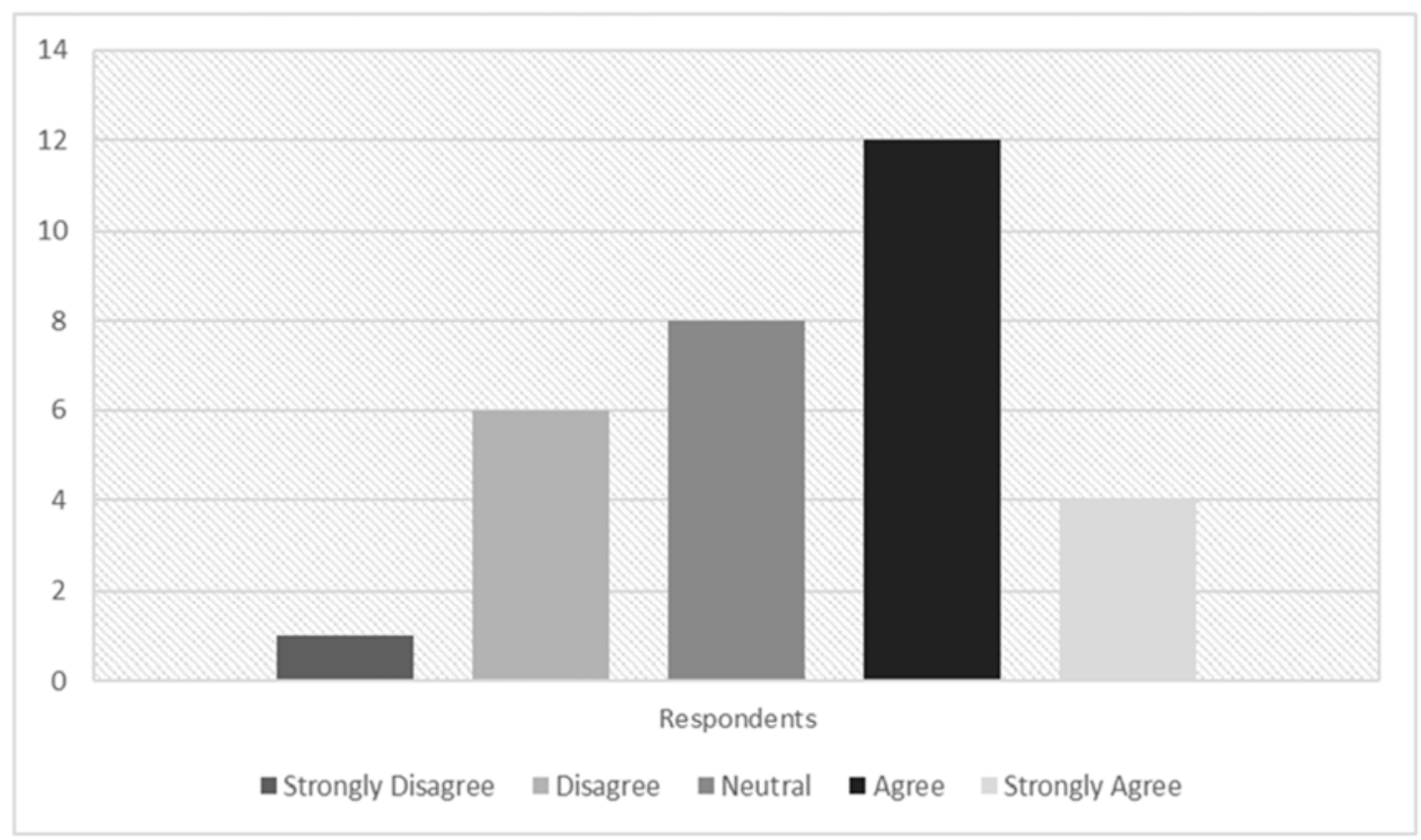

Figure 4. Frequency and Percentage Calculations of Survey Opinions.

Analytical Interpretations:

In the graph and data chart, it is observable that the purchasing power has increased for the people in Bangladesh, or at least for the majority of it. The purpose of this question is to relate the results of this to the inflation question.

\subsection{Price of Imported Goods Has Significantly Increased over the Year}

Table 7. Frequency and Percentage Calculations of Survey Opinions.

\begin{tabular}{llllll}
\hline & Frequency & Percent & Valid Percent & Cumulative Percent \\
\hline \multirow{4}{*}{ Valid } & Disagree & 3 & 9.7 & 9.7 & 9.7 \\
& Neutral & 6 & 19.4 & 19.4 & 29.0 \\
& Agree & 14 & 45.2 & 45.2 & 74.2 \\
& Strongly Agree & 8 & 25.8 & 25.8 & 100.0 \\
\hline
\end{tabular}

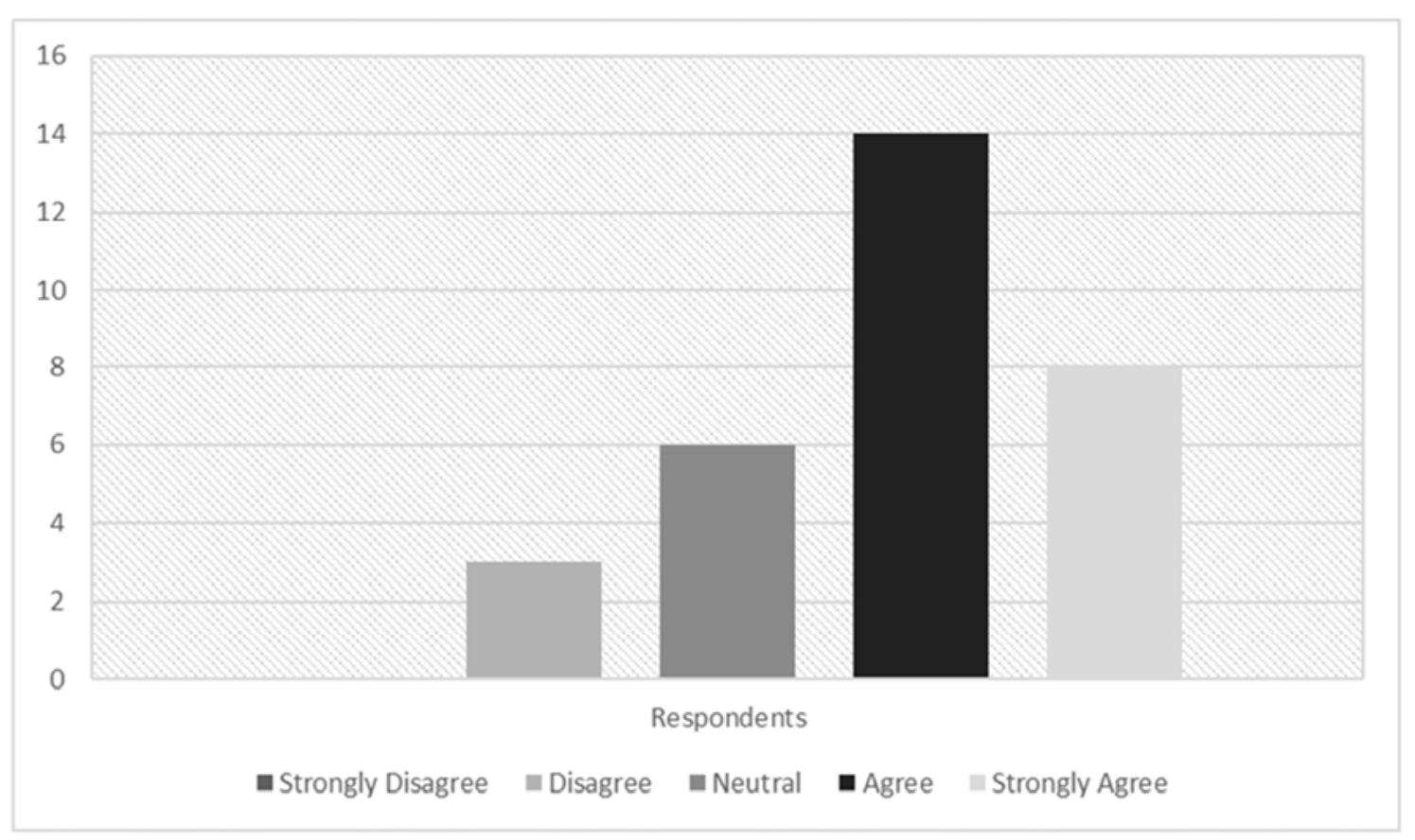

Figure 5. Frequency and Percentage Calculations of Survey Opinions. 


\section{Analytical Interpretations:}

According to the survey results, only 9.70 percentile of the surveyed officials disagree with costs of imports increasing over the year, which leaves a large percentile of population saying otherwise with the cost of imports increasing. The import incharge of both the branches emphasized on how the costs of imports rising making it difficult for importers to import goods to the country for business purpose. It also discourages the imports of supplies which are essential for exports and thus discouraging export to dampen the economy.

\subsection{Outward Remittance Has Increased over the Year}

Table 8. Frequency and Percentage Calculations of Survey Opinions.

\begin{tabular}{llllll}
\hline & Frequency & Percent & Valid Percent & Cumulative Percent \\
\hline \multirow{4}{*}{ Valid } & Strongly Disagree & 2 & 6.5 & 6.5 & 6.5 \\
& Disagree & 13 & 41.9 & 41.9 & 48.4 \\
& Neutral & 8 & 25.8 & 25.8 & 74.2 \\
& Agree & 6 & 19.4 & 19.4 & 93.5 \\
& Strongly Agree & 2 & 6.5 & 6.5 & 100.0 \\
& Total & 31 & 100.0 & 100.0 & \\
\hline
\end{tabular}

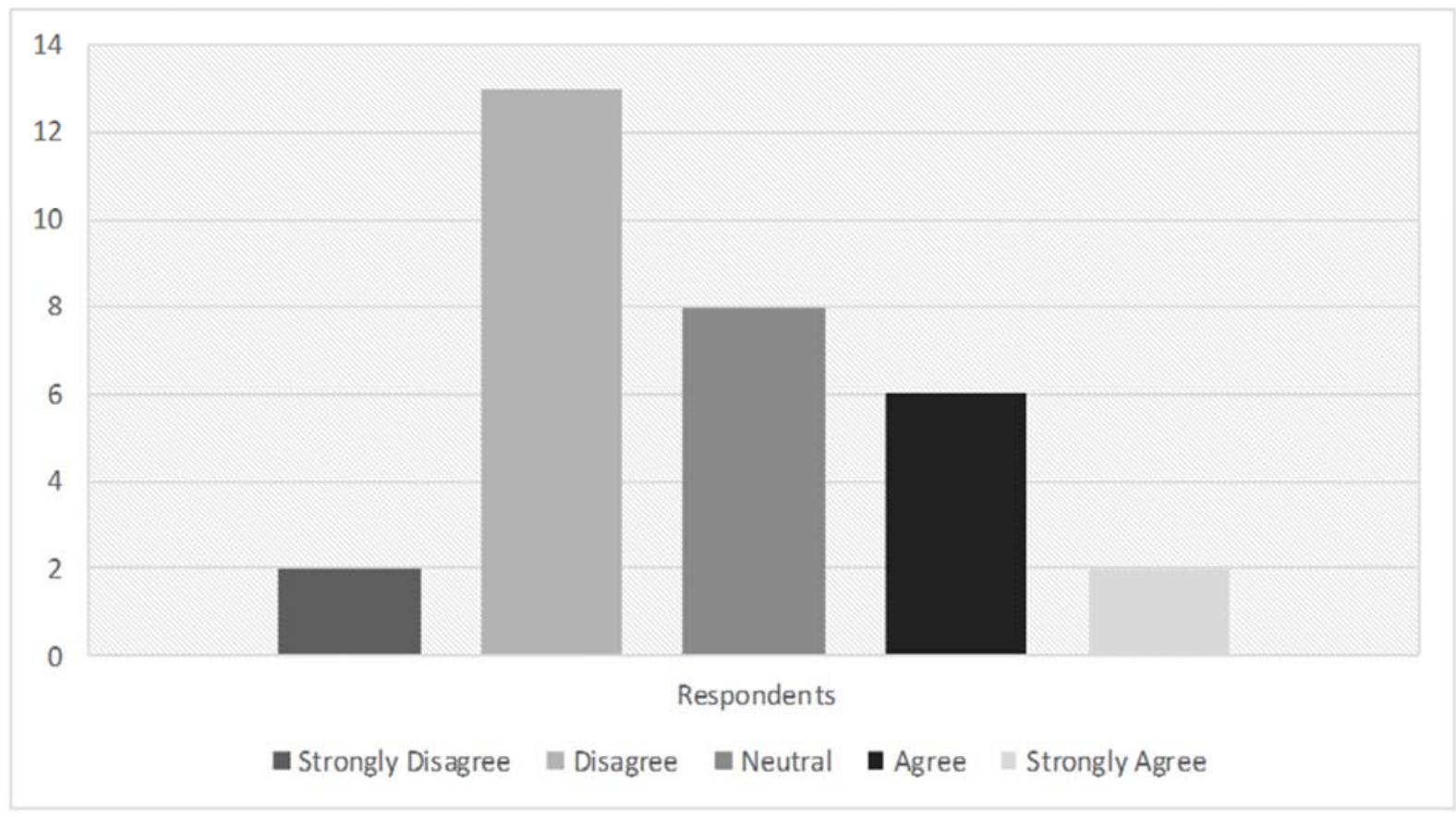

Figure 6. Frequency and Percentage Calculations of Survey Opinions.

Analytical Interpretations:

As per the graphical and data charts show, majority of the respondents replied in negative towards the question when asked if the outward remittance has increased over the year. This may be another reason why foreign reserve remained on the rise despite the inward remittance being reduced significantly. The remittance in-charge commented saying it is because of the prominence of the local private universities rising, students are being less interested over studies abroad, and so less reserve are being spent to pay the foreign institutes as tuition and students for living costs purpose, as this is the most common field that the money is being remitted towards.

\subsection{Recent Theft in the Foreign Exchange Reserve Caused for an Increase in the Exchange Rate of USD Against BDT}

Table 9. Frequency and Percentage Calculations of Survey Opinions.

\begin{tabular}{llllll}
\hline & & Frequency & Percent & Valid Percent & Cumulative Percent \\
& Strongly Disagree & 15 & 48.4 & 48.4 & 48.4 \\
\multirow{4}{*}{ Valid } & Disagree & 9 & 29.0 & 29.0 & 77.4 \\
& Neutral & 2 & 6.5 & 6.5 & 83.9 \\
& Agree & 4 & 12.9 & 12.9 & 96.8 \\
& Strongly Agree & 1 & 3.2 & 3.2 & 100.0 \\
\hline
\end{tabular}




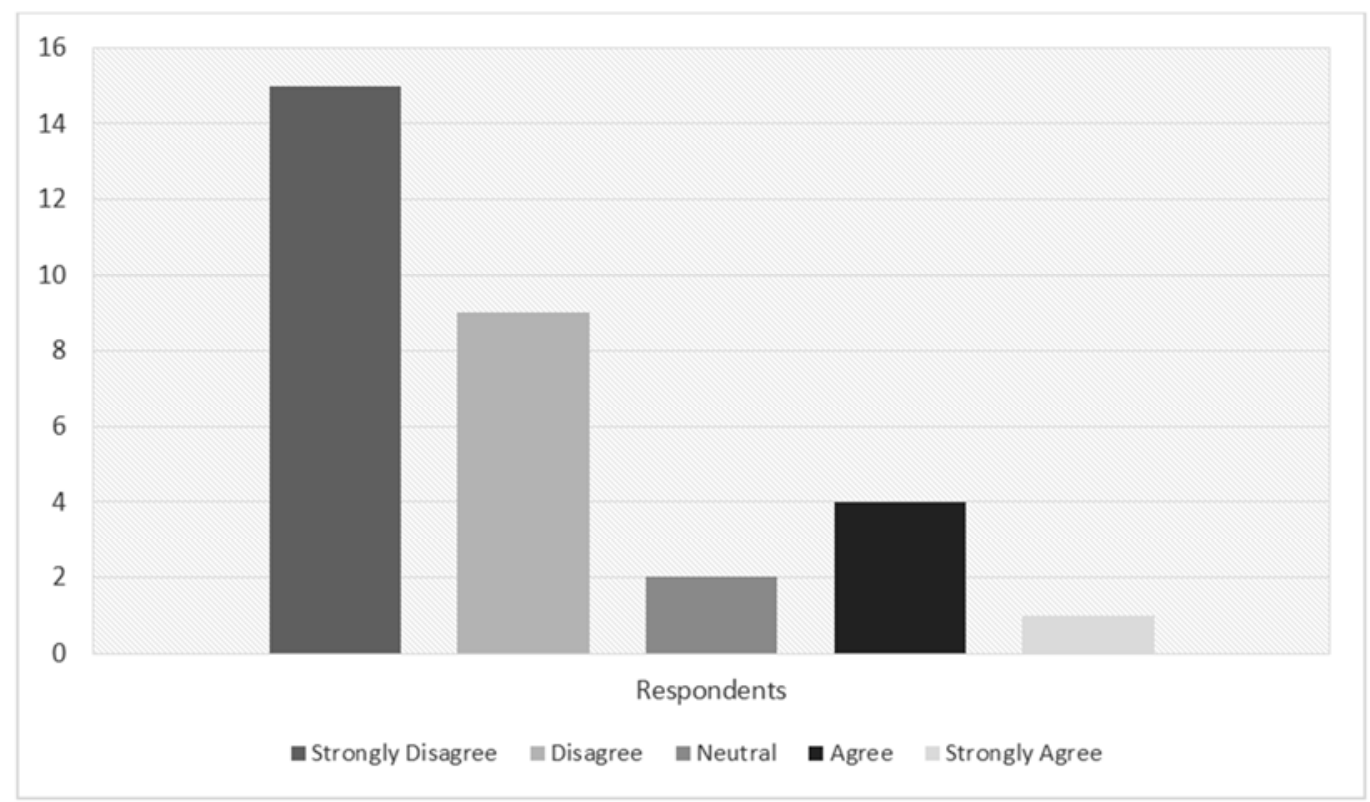

Figure 7. Frequency and Percentage Calculations of Survey Opinions.

Analytical Interpretations:

According to the news articles, the money was stolen by hackers in the month of March, 2016 but the exchange rate of USD against the local currency hasn't appreciated as it should have, as per the survey respondents' answer. Foreign Exchange incharge commented that it came as a shock to all those who had stacked up their money to hold USD expecting a rise in value in the near future as an effect to the scandal.

\subsection{Recent Theft in the Foreign Exchange Reserve Caused for Inflation}

Table 10. Frequency and Percentage Calculations of Survey Opinions.

\begin{tabular}{|c|c|c|c|c|c|}
\hline & & Frequency & Percent & Valid Percent & Cumulative Percent \\
\hline \multirow{6}{*}{ Valid } & Strongly Disagree & 6 & 19.4 & 19.4 & 19.4 \\
\hline & Disagree & 5 & 16.1 & 16.1 & 35.5 \\
\hline & Neutral & 9 & 29.0 & 29.0 & 64.5 \\
\hline & Agree & 8 & 25.8 & 25.8 & 90.3 \\
\hline & Strongly Agree & 3 & 9.7 & 9.7 & 100.0 \\
\hline & Total & 31 & 100.0 & 100.0 & \\
\hline
\end{tabular}

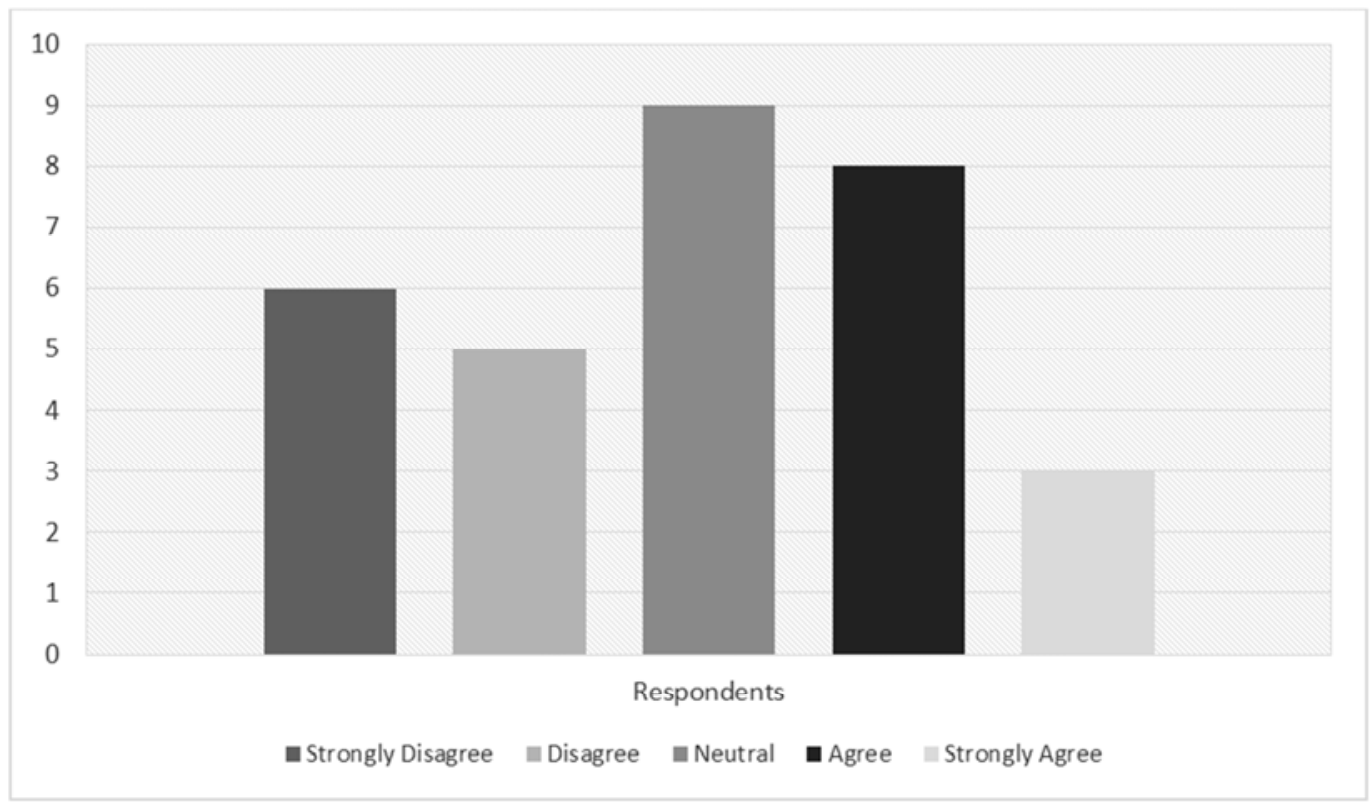

Figure 8. Frequency and Percentage Calculations of Survey Opinions. 


\section{Analytical Interpretations:}

The survey respondents' answers varied here completely. However, the majority of them agreed that there is a mild inflation in effect because of the stolen reserve, which can be observed as the inflation rate suddenly spiked from $5.62 \%$ to $5.65 \%$ from February to March before going downwards again. Since foreign exchange reserve were stolen (Nironjon Roy, 2016), and if Bangladesh Bank or the Government has taken a step to hold the exchange rate of USD stable as well as induce inflation in the market, it wouldn't be a good economic decision as it would make the people in Bangladesh more prone towards importing the goods from abroad rather than local market.

\subsection{Bangladesh Bank Is Strong on Monetary Policies to Hold the Exchange Rate Stable}

Table 11. Frequency and Percentage Calculations of Survey Opinions.

\begin{tabular}{llllll}
\hline & & Frequency & Percent & Valid Percent & Cumulative Percent \\
\hline \multirow{4}{*}{ Valid } & Strongly Disagree & 1 & 3.2 & 3.2 & 3.2 \\
& Disagree & 1 & 3.2 & 3.2 & 6.5 \\
& Neutral & 7 & 22.6 & 22.6 & 29.0 \\
& Agree & 13 & 41.9 & 41.9 & 71.0 \\
& Strongly Agree & 9 & 29.0 & 29.0 & 100.0 \\
& Total & 31 & 100.0 & 100.0 & \\
\hline
\end{tabular}

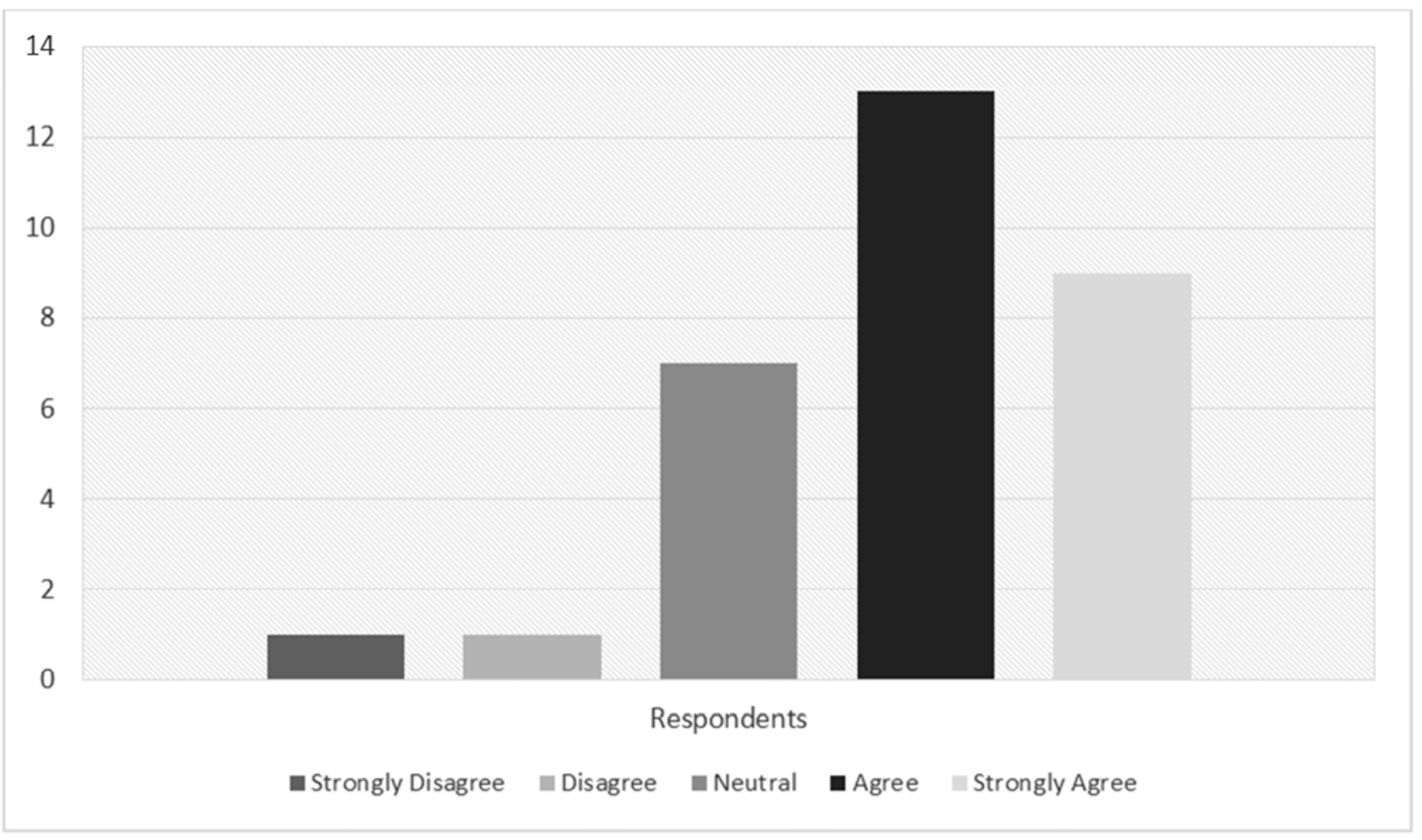

Figure 9. Frequency and Percentage Calculations of Survey Opinions.

Analytical Interpretations:

As per the output of the survey questions, the above graphical and data charts show that the surveyed officials are confident that the central bank does make it one of their priority to hold the exchange rate stable, which isn't appropriate in a managed floating exchange rate system.

\subsection{These Monetary Policies Are Effective in Keeping the Economy in Balance}

Table 12. Frequency and Percentage Calculations of Survey Opinions.

\begin{tabular}{llllll}
\hline & Frequency & Percent & Valid Percent & Cumulative Percent \\
\hline \multirow{4}{*}{ Valid } & Strongly Disagree & 3 & 9.7 & 9.7 & 9.7 \\
& Disagree & 3 & 9.7 & 9.7 & 19.4 \\
& Neutral & 5 & 16.1 & 16.1 & 35.5 \\
& Agree & 10 & 32.3 & 32.3 & 67.7 \\
& Strongly Agree & 10 & 32.3 & 32.3 & 100.0 \\
& Total & 31 & 100.0 & 100.0 & \\
\hline
\end{tabular}




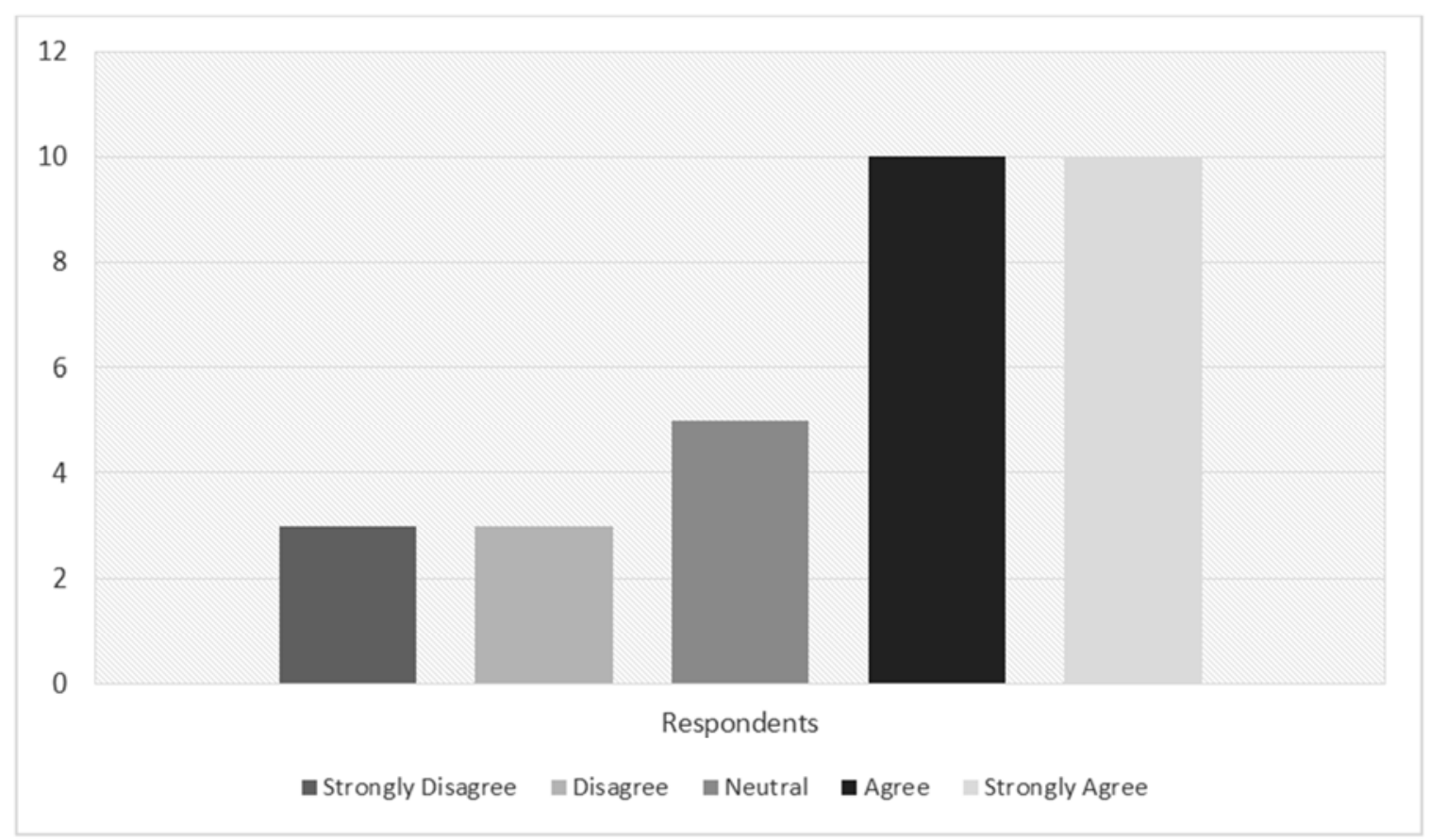

Figure 10. Frequency and Percentage Calculations of Survey Opinions.

\section{Analytical Interpretations:}

There are more officials agreeing to it than disagreeing that such monitory policies set by Bangladesh Bank help keep the national economy in balance. However, there are some strong arguments in terms of why this balance may be one of the barriers to national growth of economy.

\section{Findings}

After conducting this research, we came up with a few findings that proved our hypotheses either right or wrong. Let's list the hypotheses with the supporting or the discarding factors now:

\subsection{Hypothesis 1}

Null The changes in foreign exchange reserve can Hypothesis solely dictate the trend of the exchange rate.

Alternative Hypothesis A

Alternative Hypothesis $B$

Foreign exchange reserve does not affect the exchange rate.

Foreign exchange reserve can have an impact towards the exchange rate when the other economic conditions remain constant or change to maintain a favorable balance.

$\mathrm{H}_{0}$ - The changes in foreign exchange reserve can solely dictate the trend of the exchange rate: In the Bangladesh Bank's economic / financial time series data which is presented in 2.1. Foreign Exchange Reserve Data Summary, although it is observable that the reserve and exchange rate are in an incremental trend, the exchange rate has remained very still in the past few months despite the incremental trend of the reserve continual. Hence, this hypothesis can be rejected.
$\mathrm{H}_{\mathrm{A}}$ - Foreign exchange reserve does not affect the exchange rate: Despite the above hypothesis based on the fact that increase in FEX reserve didn't affect the exchange rate, it may be noted that the increase of Foreign Exchange Reserve indicates increase of supply of foreign currency, and therefore it should cause a decreasing effect in the exchange rate. Therefore, this hypothesis can be rejected as well.

$\mathrm{H}_{B}$ - Foreign exchange reserve can have an impact towards the exchange rate when the other economic conditions remain constant or change to maintain a favorable balance: In this case that We have studied, the inflation had an adverse effect towards the exchange rate, which is why the exchange rate remained stable despite the reserve was on the rising. If the inflation rate would decrease or remain stable in the same scenario, people would be encouraged to purchase local products, and thereby decrease the demand for foreign currency and subsequently depreciate the value of USD against BDT. With consideration of all of the above, we can accept this hypothesis.

\subsection{Hypothesis 2}

Null The changes in foreign exchange reserve

Hypothesis

Alternative Hypothesis A can solely dictate the trend of the inflation rate.

Inflation rate is not affected by the FEX reserve.

\section{or remains in a favorable balance.} Foreign exchange reserve can have an
impact towards the inflation rate when the
other economic conditions remain constant

According to the data presented on 2.1, the inflation rate did decrease with the rising reserve, but this statement on its own is not enough to prove that for one to forecast an 
increase or a decrease in the rate of inflation just by looking at the FEX reserve trend. Because as the survey results say, the purchasing power has also increased for the majority, which allowed them to be able to keep up with the pricing of the market and therefore, have an adverse effect towards the inflation. With consideration to the argument above, Null Hypothesis and Alternative Hypothesis A can be rejected, whilst the Alternative Hypothesis B can be accepted, as the FEX reserve can have impact towards the inflation rate when all other economic variable remain constant or change in a favorable direction to the effect of the FEX reserve.

\subsection{Hypothesis 3}

$\begin{array}{ll}\text { Null } & \begin{array}{l}\text { Foreign exchange reserve kept increasing } \\ \text { because of exports and inward remittance } \\ \text { Hypothesis }\end{array} \\ \text { increasing. } \\ \text { Alternative } & \begin{array}{l}\text { Foreign exchange reserve kept increasing } \\ \text { because of imports and outward } \\ \text { remittance decreasing. }\end{array}\end{array}$

Foreign exchange reserve, to increase, there must be an increase of exports or inward remittance, or a significant decrease in the import or outward remittance. Let's see which reasoning was in effect in this case scenario:

$\mathrm{H}_{0}$ - Foreign exchange reserve kept increasing because of exports and inward remittance increasing: According to the survey results, exports and inward remittance are decreasing, so this hypothesis can be rejected.

$\mathrm{H}_{\mathrm{A}}$ - Foreign exchange reserve kept increasing because of imports and outward remittance decreasing: The survey results support the fact that imports and outward remittance has been decreased over the year. However, the decrease in imports and outward remittance must be larger than the decrease in exports and inward remittance for that to happen, and since the Null Hypothesis was rejected, Alternative Hypothesis is left to be the only acceptable hypothesis.

\subsection{Hypothesis 4}

$\begin{array}{ll}\text { Null } & \begin{array}{l}\text { Bangladesh Bank and the Government played } \\ \text { with other forces / tools to keep the economy } \\ \text { in balance. }\end{array} \\ \text { Alternative } & \begin{array}{l}\text { Bangladesh Bank and the Government didn't } \\ \text { make any significant changes to keep the } \\ \text { exchange rate stable. }\end{array}\end{array}$

We have previously established in the analysis and interpretation of data from the survey results that - the inflation in effect was unconventional in the event where the reserve is increasing, because increase in the reserve would decrease the exchange rate, and people would be more prone towards imports and subsequently shift the demand curve for local products to the left, causing for a decrease in the local market product prices. Therefore, the induced inflation was a tool used by the government to keep the exchange rate stable. In addition to that, the survey results also suggest that Bangladesh Bank is very effective and focused towards the monitory policies to keep the exchange rate stable. Hence, it can be concluded that out of the two hypotheses to accept from, Null Hypothesis can be accepted.

\section{Conclusions}

To conclude this research report, we would like to emphasize once again on the importance of the exchange rate fluctuation in a growing economy. With the foreign currency exchange rate fluctuations, the banks make a lot of money, which contribute towards the growth of our national gross domestic products. The exports and inward remittances are also important factors towards building a strong foreign currency reserves which aids the national economy when needed.

\section{References}

[1] Afrin, S., Sarder, M. W., \& Nabi, M. G. (2014). The Demand for International Reserves of Bangladesh. Dhaka: Bangladesh Bank.

[2] Akther, M., Sarker, M. M., \& Khan, M. S. (2013). Sources of Exchange Rate Fluctuations in Bangladesh. Dhaka: Bangladesh Bank.

[3] Anonymous FEPD, B. B. (2016, August). Foreign Exchange Reserve's Impact on Bangladeshi Economy. (A. Malek, Interviewer)

[4] Bangladesh Bank, Central Bank of Bangladesh. (n.d.). Recent Economic Data. Retrieved from Bangladesh Bank Homepage: https://www.bb.org.bd/econdata/index.php

[5] Begum, M. N. (2014). Reserve Accumilation and Sterilized Intervention in the Foreign Exchange Market: An Empirical Analysis. Dhaka: Bangladesh Bank.

[6] Hassan, R., Chakraborty, S., Sultana, N., \& Rahman, M. M. (2016). The Impact of the Real Effective Exchange Rate on Real Export Earnings in Bangladesh. Dhaka: Bangladesh Bank.

[7] Khan, M. S., Hossain, M. S., \& Rahman, M. H. (2013). Effects of Monetary Policy on Capital Market in Bangladesh. Dhaka: Bangladesh Bank.

[8] Nironjon Roy, C. C. (2016, March 13). Money hacked from Federal Reserve: BB should move carefully. Retrieved from The Financial Express: http://www.thefinancialexpressbd.com/2016/03/13/21019

[9] Sarker, M. N., Hasan, M. S., \& Rahaman, A. (2016). Real or Nominal Shock: What Drives the Exchange Rate Movement in Bangladesh? Dhaka: Bangladesh Bank.

[10] Younus, D. S. (2010). Link between the Financial Inclusion and Economic Growth: Unconventional Monetary Policy in Bangladesh. Dhaka: Bangladesh Bank.

[11] Younus, D. S. (2014). Some Facts and Determinants of CPI Inflation in Bangladesh: Evidence from Post-Floating Exchange Rate Regime. Dhaka: Bangladesh Bank.

[12] Younus, D. S., \& Chowdhury, M. M. (2014). Real Exchange Rate and Its Impact on Export, Import and Trade Balance: Is there any $\mathrm{J}$ curve effect in Bangladesh? Dhaka: Bangladesh Bank. 